\title{
Role of Sulfites and 4-Hexylresorcinol in Microbial Growth and Melanosis Prevention of Deepwater Pink Shrimp (Parapenaeus longirostris) Using a Controlled Atmosphere
}

\author{
O. MARTÍNEZ-ALVAREZ,* M. C. GÓMEZ-GUILLÉN, AND P. MONTERO \\ Instituto del Frío (C.S.I.C.), C/ José Antonio Nováis, 10, Ciudad Universitaria 28040, Madrid, Spain
}

MS 04-100: Received 12 March 2004/Accepted 6 August 2004

\begin{abstract}
A controlled atmosphere containing $48 \% \mathrm{CO}_{2}$ and $7 \% \mathrm{O}_{2}$ was used in association with refrigeration for storage of deepwater pink shrimp (Parapenaeus longirostris). Shrimp were treated with two different concentrations of sodium metabisulfite or 4-hexylresorcinol and subjected to the controlled atmosphere immediately after capture onboard ship or on arrival in port. Total volatile basic nitrogen, total viable counts, enterobacteria, lactic acid bacteria, and luminescent bacteria were determined, and black spot progression was evaluated. The combined effect of controlled atmosphere and melanosis inhibitors was used to delay black spot development as compared to the shrimp stored in ice alone. Storage under the controlled atmosphere without ice limited microbiological quality, namely, total viable counts, but enterobacterial growth was lower.
\end{abstract}

The shelf life of fresh crustaceans is limited primarily by the formation, during cold storage, of large quantities of free amino acids and other substances that are ideal substrates for microbial growth, coupled with the onset of melanosis, produced by polyphenol oxidase (PPO). This enzyme is responsible for sclerotization (hardening) of the exoskeleton after molting (2), and indeed certain workers have observed a relationship between molt stage and black spot formation in shrimp $(10,24)$. The discoloration appears to be harmless to consumers, but it nonetheless greatly reduces market value and hence results in substantial economic loss.

Sulfites and sulfite derivatives have traditionally been used as melanosis inhibitors (11). However, their effectiveness is variable, they do not prevent black spot completely, and they may also sometimes pose a health risk $(31,32)$, mainly in the form of allergic reactions and severe asthma attacks in asthmatics. Benzoic acid, kojic acid, and 4-hexylresorcinol, or cumic acid, have proved to be partially effective black spot inhibitors (23). These chemical agents are capable of stopping black spot formation nearly completely. Nevertheless, microbial spoilage continues and becomes the factor limiting the shelf life of crustaceans kept under chilled storage (5).

There is therefore a need to find alternatives that will inhibit black spot formation, avoid health safety issues for consumers, and retard microbial growth. Sivertsvik and others (27) reported that use of a controlled atmosphere (CA) rich in $\mathrm{CO}_{2}$ and poor in $\mathrm{O}_{2}$ during cold storage helped delay melanosis formation while at the same time delaying microbial growth. Inhibition of the growth of microorganisms by controlled or modified atmospheres has been described in packaged shrimp $(16,17,19)$. However, very little in-

* Author for correspondence. Tel: +34 91 5492300; Fax: +34 91 5493627; E-mail: oscarm@if.csic.es. formation is available on the shelf life of crustaceans treated with CA onboard ship or immediately after off-loading in port and then followed by cold storage.

An earlier work found that an atmosphere with approximately $55 \% \mathrm{CO}_{2}$, in combination with sulfiting, inhibited black spot entirely in iced shrimp for at least 2 weeks of storage. However, the texture of the product after cooking was deteriorated with significant losses in shrimp flavor; an effect ascribed to diffusion of the $\mathrm{CO}_{2}$ into the flesh as the ice melted. Various researchers $(3,13)$ have also described adverse effects on fish color and texture in atmospheres overly enriched with $\mathrm{CO}_{2}$, in large part caused by increased muscle acidity due to diffusion of the $\mathrm{CO}_{2}(8$, 17, 27).

The object of this study was to establish whether treatment using a controlled atmosphere $\left(48 \% \mathrm{CO}_{2}, 7 \% \mathrm{O}_{2}\right)$ immediately after capture onboard ship or on arrival in port and application of 4-hexylresorcinol or sulfites combined to have a greater inhibitory effect on melanosis, thereby prolonging the shelf life of shrimp in cold storage.

\section{MATERIALS AND METHODS}

The experiment was performed using deepwater pink shrimp (Parapenaeus longirostris) caught off the coast of southern Spain (Cadiz) by trawlers in November 2002. Shrimp mean size and weight were $7 \pm 1 \mathrm{~cm}$ and $5 \pm 1.5 \mathrm{~g}$, respectively. Onboard ship they were separated from the bycatch, washed with seawater, and placed in perforated polystyrene boxes (approximately $1 \mathrm{~kg}$ per box). Except for one treatment for which no inhibitors were used (treatment control), all the shrimp were dusted with either 4-hexylresorcinol plus sorbitol as excipient $(0.25 \mathrm{~g}$ powder per $100 \mathrm{~g}$ shrimp) (treatment R) or a commercial sodium metabisulfitebased product (Freskor HA-5501, Hasenosa, Spain) at a recommended concentration of $4 \%$ (treatment S4\%), and also at $2 \%$ (treatment S2\%), to test the possibility of lowering the sulfite levels used with the protective atmosphere. Inhibitor concentration 
has been expressed as grams of commercial product per $100 \mathrm{~g}$ of shrimp. All lots were chilled by covering with flaked ice to facilitate diffusion of the black spot inhibitors into the shrimp and to keep shrimp temperature down until landing. Two replications were performed for all treatments.

A portion of each of the treatments with the black spot inhibitors was placed in airtight stainless steel containers to be subjected to a controlled atmosphere onboard ship $\left(\mathrm{CA}_{\text {board }}\right)$ (treatments R-CA $\mathrm{C}_{\text {board }}, \mathrm{S} 4 \%-\mathrm{CA}_{\text {board }}$, and $\left.\mathrm{S} 2 \%-\mathrm{CA}_{\text {board }}\right)$. The same was done with a portion of the treatment without any inhibitor (treatment control- $\mathrm{CA}_{\text {board }}$ ) for use as a control. The containers were immediately filled with a previously prepared gas mixture consisting of $7 \% \mathrm{O}_{2}$ and $48 \% \mathrm{CO}_{2}$, the remainder being $\mathrm{N}_{2}$. The composition of the atmosphere was chosen according to preliminary trials.

On arrival in port $8 \mathrm{~h}$ after capture, the containers were opened to remove the ice from the boxes. They were then immediately resealed and placed in cold storage $\left(2^{\circ} \mathrm{C}\right)$, and the controlled atmosphere gas mixture was replaced.

Another portion of the shrimp with added inhibitors was to be stored in the controlled atmosphere upon arrival in port (CAport). Then, the ice was likewise removed and shrimp were placed in cold stored containers, which were filled with the same gas mixture (treatments R-CA $A_{\text {port }}, \mathrm{S} 4 \%-\mathrm{CA}_{\text {port }}, \mathrm{S} 2 \%-\mathrm{CA}_{\text {port }}$, and control-CA $\left.\mathrm{A}_{\text {port }}\right)$. The lots that did not undergo CA treatment were kept in ice throughout the entire storage period (treatments R-ice, S4\%ice, S2\%-ice, control-ice). The containers and the non-CA-treated lots were transported to Madrid (Spain) in a refrigerated truck that left the port within $12 \mathrm{~h}$ of landing. On arrival they were placed in cold storage at $2^{\circ} \mathrm{C}$, and the CA was refreshed over the course of storage to ensure that the gas mixture remained stable.

A portion of each of the $\mathrm{CA}_{\text {port }}$-treated lots was removed from the containers after $48 \mathrm{~h}$ and held in chilled storage covered with ice. The object was to be able to assess the possible residual effect of the $\mathrm{CO}_{2}$ over the remainder of the storage period (treatments R-CA $\mathrm{C}_{\text {residual }}, \mathrm{S} 4 \%-\mathrm{CA}_{\text {residual }}$, and $\mathrm{S} 2 \%-\mathrm{CA}_{\text {residual }}$ ).

Over the 10-day storage period a group of trained panelists routinely evaluated shrimp appearance every 2 days (14 individuals per treatment per evaluation), scoring melanosis according to a scale of from 1 to 4 , where $1=$ complete absence of black spots; $2=$ a few small spots on the carapace; $3=$ considerable spotting on the carapace; $4=$ substantial spotting over the entire shrimp. The assessors also examined shrimp discoloration and the commercial viability of each treatment. On day 2 of storage a taste test was performed for all treatments to detect possible shrimp aromas or flavors that might be related to the melanosis inhibitors or the CA employed. These aromas and flavors were rated as being either absent or present.

Total volatile basic nitrogen (TVBN) determinations were carried out in triplicate over the storage period using the method of Antonacopoulos and Vyncke (1). Exactly $10 \mathrm{~g} \pm 0.1 \mathrm{~g}$ of the ground sample were weighed in a suitable container and homogenized for 2 min with $100 \mathrm{ml}$ of $6 \%$ perchloric acid solution. After being filtered, the extract was alkalinized with $20 \%$ sodium hydroxide solution and submitted to steam distillation. The volatile base components were absorbed by an acid receiver and determined by titration of the absorbed bases.

For microbiological analyses, duplicate shrimp samples were blended (1:9 dilution) with peptone water (Oxoid, Basingstoke, UK) containing $0.85 \%$ added $\mathrm{NaCl}$ in a Stomacher model 400 type BA 7021 Lab Blender (Seward Medical, Colworth London, UK) for $1 \mathrm{~min}$. Total viable counts (TVC) and luminescent bacteria were determined by spread plating on Long and Hammer's agar with $1 \% \mathrm{NaCl}(28)$, incubated at $15^{\circ} \mathrm{C}$. Counts were per-

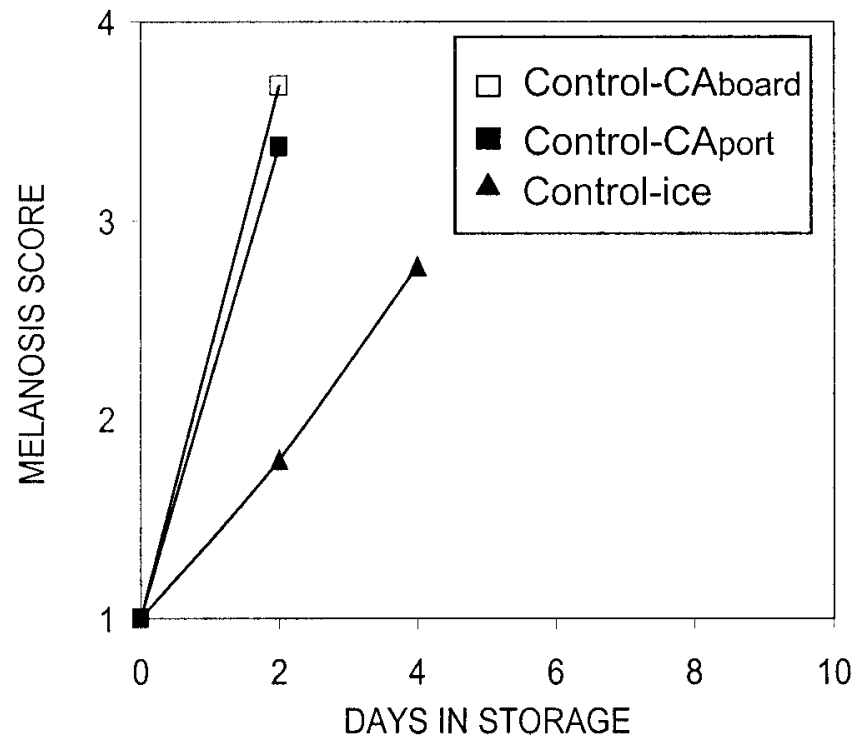

FIGURE 1. Melanosis scores in shrimp stored without black spot inhibitors (control) over the storage period. Control-ice $=$ stored in ice; control-CA $A_{\text {board }}=$ onboard $C A$ treatment; control-CA $A_{\text {port }}$ = in-port CA treatment. Melanosis index: $1=$ complete absence of black spots; $2=$ a few small spots on the carapace; $3=$ considerable spotting on the carapace; $4=$ substantial spotting over the entire shrimp.

formed after 3 days (in darkness for luminescent bacteria) and after 5 days (for TVC), Enterobacteria were determined on violet red bile glucose agar $\left(30^{\circ} \mathrm{C}, 2\right.$ days $)$, according to López-Caballero et al. (19). Lactic acid bacteria (LAB) were incubated in deMan Rogosa Sharpe agar at $30^{\circ} \mathrm{C}$ for 3 to 5 days, according to Man et al. (9).

Two-way analysis of variance was performed to evaluate the statistical significance of the differences between mean TVBN value pairs using a significance level setting of $P \leq 0.05$. The Statgraphics plus 2.1 computer program (STSC, Inc., Rockville, Md.) was used for statistical processing. Melanosis evaluation scores over the storage period were fitted to a curve by regressing the mean daily scores for all the panelists for each treatment.

\section{RESULTS AND DISCUSSION}

Effect of the CA on the shrimp stored without inhibitors. The use of a $\mathrm{CO}_{2}$-enriched, $\mathrm{O}_{2}$-poor $\mathrm{CA}$ (in both onboard and in-port treatments) did not prevent black spot development, showing higher values than those observed in shrimp stored in ice without any CA treatment (Fig. 1). This agreed with the findings of Lannelongue et al. (16), who attributed reduced intensity of black discoloration to washing of the shrimp by melting ice. This may also explain partially the TVBN values were higher than $30 \mathrm{mg}$ / $100 \mathrm{~g}$ after storage for 4 days in the CA-treated treatments (Table 1).

Initial microbial counts were generally high in all control treatments (Table 2), a finding doubtless ascribable to the absence of added preservatives. The TVC and luminescent bacterial counts were lower in the shrimp stored in ice after 2 days of storage. The melting ice could have washed away bacteria present on the surface of the shrimp, as has been suggested by Lannelongue et al. (15). Luminescent bacteria, chiefly the gram-negative organism Photobacter- 
TABLE 1. Total volatile basic nitrogen (TVBN) (means and twoway analysis of variance) in shrimp stored without blackspot inhibitors (control) over the storage period

\begin{tabular}{|c|c|c|c|}
\hline \multirow[b]{2}{*}{$\operatorname{Lots}^{a}$} & \multicolumn{3}{|c|}{ Days of storage } \\
\hline & 2 & 4 & 7 \\
\hline Control-CA board $_{\text {b }}$ & $19.08 \mathrm{AX}^{b}$ & $34.89 \mathrm{BXY}$ & \\
\hline Control-CA port & $27.95 \mathrm{AX}$ & $38.78 \mathrm{AX}$ & \\
\hline Control-ice & $18.26 \mathrm{AX}$ & $23.05 \mathrm{AY}$ & $21.69 \mathrm{~A}$ \\
\hline \multicolumn{4}{|c|}{$\begin{array}{l}{ }^{a} \text { Control-ice, stored in ice; Control-CA } \mathrm{CA}_{\text {board, }} \text {, onboard CA treat- } \\
\text { ment; Control-CA } \mathrm{A}_{\text {port }} \text {, in-port CA treatment. }\end{array}$} \\
\hline \multicolumn{4}{|c|}{$\begin{array}{l}{ }^{b} \text { Different letters }(\mathrm{A}, \mathrm{B}) \text { in the same row indicate significant dif- } \\
\text { ferences }(P \leq 0.05) \text { as a function of storage time; different let- } \\
\text { ters }(\mathrm{X}, \mathrm{Y}) \text { in the same column indicate significant differences } \\
(P \leq 0.05) \text { as a function of treatment. }\end{array}$} \\
\hline
\end{tabular}

ium phosphoreum, have been regarded as one of the principal causes of spoilage in fish products stored in atmospheres with high $\mathrm{CO}_{2}$ contents $(6,27)$, producing high levels of trimetilamine. In this study, luminescent bacterial counts were slightly higher in the $\mathrm{CA}_{\text {port }}$ treatment than in the $\mathrm{CA}_{\text {board }}$, which may be ascribable to the residence time of the shrimp onboard the fishing vessel prior to CA treatment, around $8 \mathrm{~h}$. So, $7 \% \mathrm{O}_{2}$ was not enough to inhibit the luminescence bacteria growth along storage.

LAB levels were slightly higher in the $\mathrm{CA}_{\text {board }}$ treatment. Partially anoxic conditions with higher acid levels due to the $\mathrm{CO}_{2}$ encouraged LAB growth, and consequently the growth of the ordinary spoilage microflora was partially inhibited $(5,17,27)$. The change in the balance in favor of the lactic acid microflora (17) is very important, given that these microorganisms do not produce indole (17) and trimetilamine (19) in significant amount. Gram-negative microorganisms, and Enterobacteriaceae in particular, show a significant production of indole levels, which have been used by the U.S. Food and Drug Administration to validate the sensory evaluation of shrimp decomposition (22).

Refrigeration at higher $\mathrm{CO}_{2}$ concentrations has resulted in reported slow enterobacterial growth in shrimp (17). Lannelongue et al. (16) described gram-negative bacteria generally as being sensitive to $\mathrm{CO}_{2}$ and to low temperatures. Nevertheless, after storage for 2 days the total counts of presumptive Enterobacteriaceae (26) were close to $10^{3}$ $\mathrm{CFU} / \mathrm{g}$. No putative washing effect by the melting ice was discernible in this case.

Effect of the CA on the sulfited shrimp. Dusting of commercial black spot inhibitor at a concentration of $4 \%$ plus storage in ice sufficed to halt melanosis development
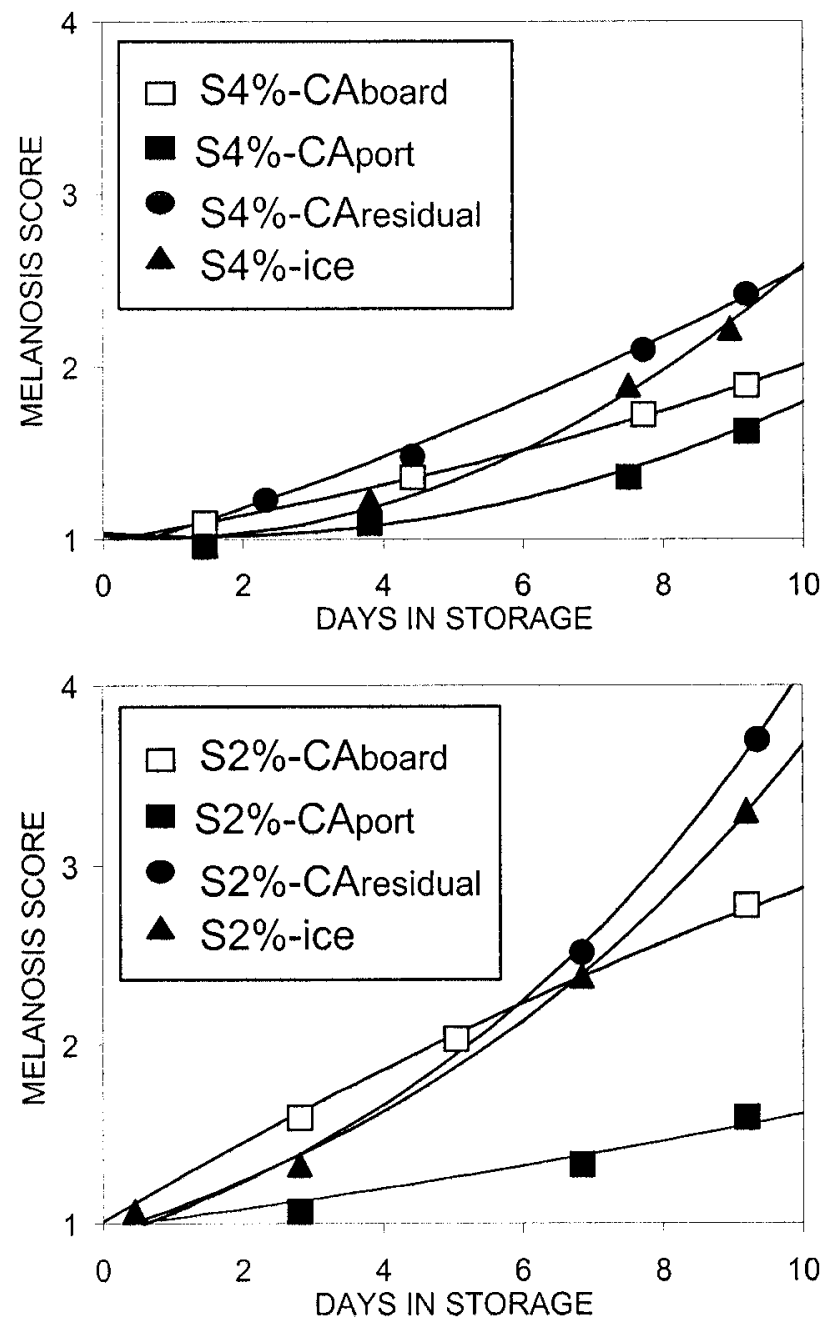

FIGURE 2. Melanosis scores in shrimp treated by adding sulfites at concentrations of $4 \%$ (wt/wt) (S4\%) and 2\% (wt/wt) (S2\%) during cold storage. S4\%-ice, S2\%-ice = stored in ice; $54 \%$ $C A_{\text {board }}, S 2 \%-C A_{\text {board }}=$ onboard $C A$ treatment; $S 4 \%-C A_{\text {port }}$, $S 2 \%-C A_{\text {port }}=$ in-port $C A$ treatment; $S 4 \%-C A_{\text {residual }}, S 2 \%-C A_{\text {residual }}$ $=$ stored in ice after in-port CA treatment for $48 \mathrm{~h}$ (residual effect). Melanosis index as in Figure 1.

in the shrimp and to keep shrimp appearance acceptable for at least 4 days without the need for any CA treatment (Fig. 2 ). The acceptability period was appreciably shorter when the black spot inhibitor was added at a concentration of $2 \%$.

$\mathrm{CA}_{\text {port }}$ treatment of shrimp in combination with sulfiting at both concentrations, $4 \%$ and $2 \%$, held black spot formation to lower levels over the storage period than with $\mathrm{CA}_{\text {board }}$ treatment. Thus, addition of a low concentration of

TABLE 2. Microbiological counts (log CFU/g) in shrimp (means plus or minus standard deviation) with no additives (control) after 2 days of cold storage

\begin{tabular}{lcccc}
\hline \multicolumn{1}{c}{ Lots $^{a}$} & TVC & Luminescent bacteria & Lactic acid bacteria & Enterobacteria \\
\hline Control-CA & $6.50 \pm 0.02$ & $3.7 \pm 0.00$ & $2.32 \pm 0.04$ & $<2$ \\
Control-CA & $6.59 \pm 0.03$ & $4.24 \pm 0.24$ & $2.07 \pm 0.03$ & $<2$ \\
Control-ice & $5.02 \pm 0.03$ & $3.00 \pm 0.00$ & $2.09 \pm 0.01$ & $2.24 \pm 0.24$ \\
\hline
\end{tabular}

${ }^{a}$ Control-ice, stored with ice; Control-CA $\mathrm{Coard}_{\text {, }} \mathrm{CA}$ applied on board; Control-CA $\mathrm{A}_{\text {port }}$, CA applied in port. 
TABLE 3. Total volatile basic nitrogen (TVBN) (means and analysis of variance) in shrimp treated by adding sulfites at concentrations of $4 \%(w t / w t)(S 4 \%)$ and $2 \%(w t / w t)(S 2 \%)$ during cold storage

\begin{tabular}{|c|c|c|c|}
\hline \multirow[b]{2}{*}{ Lots $^{a}$} & \multicolumn{3}{|c|}{ Days of storage } \\
\hline & 2 & 4 & 7 \\
\hline $\mathrm{S} 4 \%-\mathrm{CA}_{\text {board }}$ & $26.06 \mathrm{AY}^{b}$ & 35.07 BXYZ & $69.28 \mathrm{CZ}$ \\
\hline $\mathrm{S} 4 \%-\mathrm{CA}_{\text {port }}$ & $26.06 \mathrm{AY}$ & 40.14 BYZ & $66.38 \mathrm{CZ}$ \\
\hline $\mathrm{S} 4 \%-\mathrm{CA}_{\text {residual }}$ & $26.06 \mathrm{AY}$ & $31.47 \mathrm{AX}$ & $39.67 \mathrm{BY}$ \\
\hline S4\%-ice & $19.36 \mathrm{AX}$ & $18.99 \mathrm{AW}$ & $18.50 \mathrm{AX}$ \\
\hline $\mathrm{S} 2 \%-\mathrm{CA}_{\text {board }}$ & $26.13 \mathrm{AY}$ & 35.76 вXYZ & $62.02 \mathrm{CZ}$ \\
\hline $\mathrm{S} 2 \%-\mathrm{CA}_{\text {port }}$ & $26.92 \mathrm{AY}$ & $41.65 \mathrm{BZ}$ & $62.98 \mathrm{CZ}$ \\
\hline $\mathrm{S} 2 \%-\mathrm{CA}_{\text {residual }}$ & $26.92 \mathrm{AY}$ & 33.42 вху & 38.19 ву \\
\hline S2\%-ice & $18.13 \mathrm{AX}$ & $19.52 \mathrm{AW}$ & $18.30 \mathrm{AX}$ \\
\hline
\end{tabular}

${ }^{a} \mathrm{~S} 4 \%$-ice, $\mathrm{S} 2 \%$-ice, stored in ice; $\mathrm{S} 4 \%-\mathrm{CA}_{\text {board }}, \mathrm{S} 2 \%-\mathrm{CA}_{\text {board }}$, onboard CA treatment; $\mathrm{S} 4 \%-\mathrm{CA}_{\text {port }}, \mathrm{S} 2 \%-\mathrm{CA}_{\text {port }}$, in-port CA treatment; $\mathrm{S} 4 \%-\mathrm{CA}_{\text {residual }}, \mathrm{S} 2 \%-\mathrm{CA}_{\text {residual }}$, stored in ice after in-port CA treatment for $48 \mathrm{~h}$ (residual effect).

${ }^{b}$ Different letters $(\mathrm{A}, \mathrm{B}, \mathrm{C})$ in the same row indicate significant differences $(P \leq 0.05)$ as a function of storage time; different letters $(\mathrm{W}, \mathrm{X}, \mathrm{Y}, \mathrm{z})$ in the same column indicate significant differences $(P \leq 0.05)$ as a function of treatment.

sulfites in combination with CA treatment may be a suitable means of preventing melanosis.

In terms of melanosis development and the possible residual effect of the $\mathrm{CO}_{2}$, CA treatment for $48 \mathrm{~h}$ followed by conventional storage in ice $\left(\mathrm{CA}_{\text {residual }}\right)$ did not yield better results than sulfiting alone, irrespective of the concentration employed. Surprisingly, not only did the CA treatments not yield any apparent benefit in terms of shrimp appearance, they proved detrimental to sensory quality.

The TVBN content in the CA-treated shrimp exceeded $30 \mathrm{mg} / 100 \mathrm{~g}$ of flesh from day 4 (Table 3), in spite of the beneficial effects of storing under $\mathrm{CO}_{2}$ (17). In contrast, in the shrimp stored in ice from the outset, the TVBN level held steady at around $20 \mathrm{mg} / 100 \mathrm{~g}$ because of the melting ice effect, with no significant differences $(P \leq 0.05)$ observed according to the sulfite concentration employed (Table 3). Furthermore, the values recorded were similar to those recorded for the shrimp stored without the use of inhibitors (Table 1). The shrimp treated with $\mathrm{CA}_{\text {residual }}$ exhibited intermediate TVBN levels $(P \leq 0.05)$ at the end of storage. Thus, the washing effect of the melting ice would appear to be a more important factor for this index than the effect of either the CA treatment or sulfiting.

Neither the addition of sulfites, which certain workers have regarded as antimicrobial agents $(4,20)$ nor the high $\mathrm{CO}_{2}$ levels prevented high total viable microbial counts after 2 days of storage (Table 4). However, the microflora could be dominated by gram-positive bacteria, which are much more resistant to $\mathrm{CO}_{2}(17,27)$. The lowest counts were observed in the shrimp stored in ice without CA treatment until day 7 , after which the values were similar to those in the other treatments, in consonance with the results reported by López-Caballero et al. (19). Siverstsvik et al. (27) showed that $\mathrm{CO}_{2}$ can inhibit the normal spoilage flora, increasing shelf life significantly. The absence of this effect

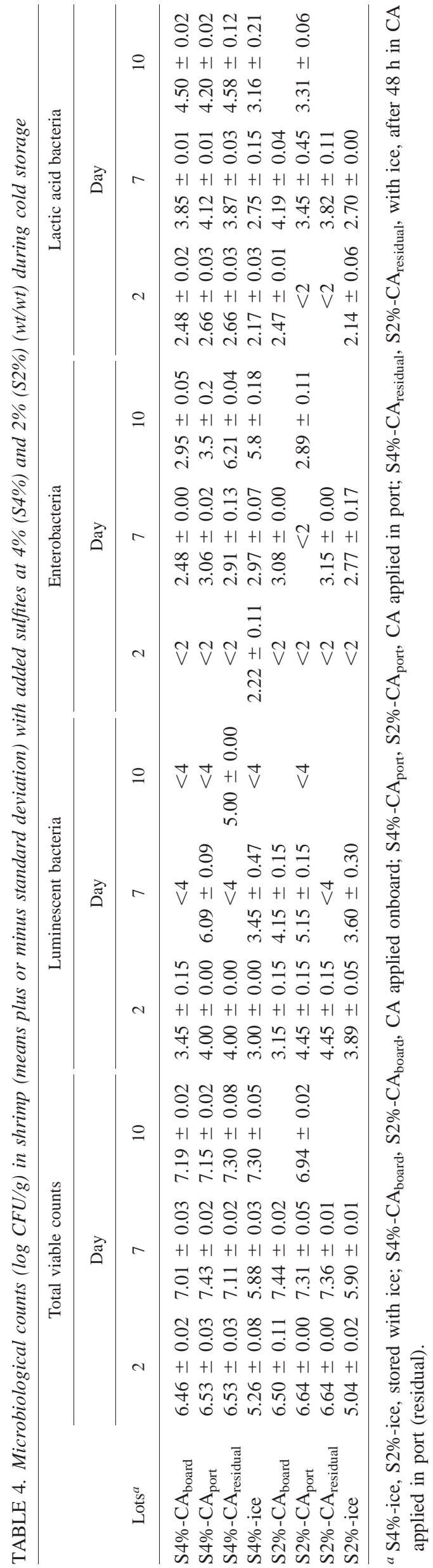


may be due to the lack of melting ice effect. In addition, unlike the findings observed by Stammen et al. (29), the residual effect of the $\mathrm{CO}_{2}$ did not appear to have any beneficial influence on preservation.

As in the case of the shrimp without added inhibitor, luminescent bacterial counts were slightly lower in the CAboard treatments compared with those $\mathrm{CA}_{\text {port }}$ treatments, irrespective of the sulfite concentration used (Table 4). Sulfiting did not directly affect the growth of these microorganisms. As discussed by Dalgaard et al. (7), this slight inhibitory effect of the $\mathrm{CA}_{\text {board }}$ treatment can be attributed more to the lower $\mathrm{O}_{2}$ levels than to the higher $\mathrm{CO}_{2}$ levels, since Photobacterium is highly resistant to $\mathrm{CO}_{2}$. Counts were somewhat higher than for the treatments stored in ice without any $\mathrm{CA}$ treatment.

CA treatment of sulfited shrimp was conducive to LAB growth over the storage period (Table 4), although growth was low because of the low temperature (18). The growth of LAB spp. in high $\mathrm{CO}_{2}$ concentrations was reported by Stenström (30). The differences observed with respect to the lot that did not undergo CA treatment can be attributed to the washing effect of the melting ice and to the higher acidity levels caused by diffusion of the $\mathrm{CO}_{2}$. This effect also appeared to be unrelated to the sulfite concentration used, and similarly no clear differences were discernible with respect to $\mathrm{CA}_{\text {board }}$ or $\mathrm{CA}_{\text {port }}$ treatment. Regarding the possible residual effect of the $\mathrm{CO}_{2}$ on the shrimp, at the end of 10 days counts of LAB were similar to those in the $\mathrm{CA}$ treatments and significantly higher than those in the treatment stored in ice from the start. This indicates that there really was an appreciable residual effect on the growth of LAB, which was not counteracted by the washing effect of the melting ice.

The presumptive enterobacteria grew slightly during the storage period in CA (Table 4). Counts were similar in all treatments until day 7 . However, by day 10 growth was considerably higher in the treatments stored in ice. It thus appears that under the conditions of this experiment the $\mathrm{CO}_{2}$ exerted no residual influence and that $\mathrm{CA}$ treatment must be ongoing if it is to be able to limit the growth of these microorganisms. The high $\mathrm{CO}_{2}$ content, combined with the presence of higher levels of LAB, may have been responsible for the lower growth recorded in the CA treatments. López-Caballero et al. (19) reported enterobacterial counts similar to those recorded here during CA storage of shrimp using $45 \% \mathrm{CO}_{2}, 5 \% \mathrm{O}_{2}$, and $50 \% \mathrm{~N}_{2}$ and even higher counts using $40 \% \mathrm{CO}_{2}, 30 \% \mathrm{O}_{2}$, and $30 \% \mathrm{~N}_{2}$. Here again, the concentration of the added sulfite likewise did not appear to exhibit any definite influence.

According to the sensory analysis performed $48 \mathrm{~h}$ after capture, the shrimp gave off a slightly acidic odor when the containers were opened, but this odor dissipated over time. On cooking a certain sour though not unpleasant taste was perceptible, possibly caused by diffusion of the $\mathrm{CO}_{2}$ into the flesh (17). In any case, half of the panelists were unable to perceive this taste.

Effect of the CA on the shrimp treated with 4-hexylresorcinol. Based on preliminary studies into the use of

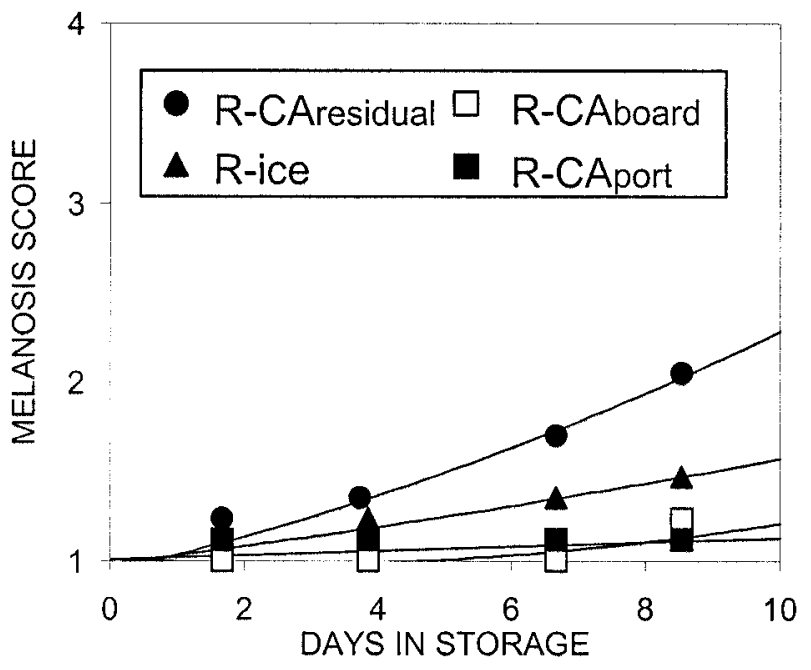

FIGURE 3. Melanosis scores in shrimp treated by adding 4-hexylresorcinol at a concentration of $0.25 \%(w t / w t)(R)$ during cold storage. $R$-ice $=$ stored in ice; $R$-CA board $=$ onboard $C A$ treatment; $R$-CA $A_{\text {port }}=$ in-port $C A$ treatment; $R$ - $C A_{\text {residual }}=$ stored in ice after in-port $C A$ treatment for 48 h (residual effect). Melanosis index as in Figure 1.

4-hexylresorcinol to stop melanosis in white shrimp (23), a concentration of $0.25 \mathrm{~g}$ of 4-hexylresorcinol per $100 \mathrm{~g}$ of shrimp was selected as the minimum dose required to prevent the appearance of black spot for at least 7 days in shrimp caught in autumn, when higher concentrations of melanosis inhibitors are needed to prevent black spot formation (23). This effective dose was appreciably higher than the concentrations reported by other researchers $(12$, $21,25)$. These differences may be due to the fact that different species are involved, certain physiological states may be more susceptible than others, or different volumes of shrimp or application methods may have been used.

As shown in Figure 3, combining a $\mathrm{CO}_{2}$-enriched atmosphere with $0.25 \%$ 4-hexylresorcinol resulted in the nearly complete prevention of melanosis over 9 days of the storage period. In any case, a certain greenish hue on the carapace was visible in all the treatments from day 4 onward, associated with the use of 4-hexylresorcinol in shrimp caught in autumn, as previously reported (23). The treatment stored in ice without CA treatment underwent a substantial increase in the level of melanosis after 7 days, an increase that appeared still sooner in the $\mathrm{CA}_{\text {residual-treat- }}$ ed shrimp. The combination of CA treatment plus 4-hexylresorcinol changed the greenish hue on the carapace to a light gold.

The results for TVBN content revealed a trend very similar to that for the sulfited treatments, with slightly lower values at the end of storage (Table 5). TVBN levels increased significantly $(P \leq 0.05)$ in the CA treatments, which were stored without ice. As in the other experimental cases already referred to above, values were higher than those recommended by Huss (14). In contrast, the treatment stored only in ice the whole time had constant TVBN levels that were less than $30 \mathrm{mg} / 100 \mathrm{~g}$ of flesh.

Viable aerobe counts (Table 6) at the start of storage were similar to those for the black spot inhibitor-free and 
TABLE 5. Total volatile basic nitrogen (TVBN) (means and twoway analysis of variance) in shrimp treated by adding 4-hexylresorcinol at a concentration of $0.25 \%(w t / w t)(R)$ during cold shrimp

\begin{tabular}{lccc}
\hline & \multicolumn{3}{c}{ Days of storage } \\
\cline { 2 - 4 } \multicolumn{1}{c}{ Lots $^{a}$} & 2 & 4 & 7 \\
\hline R-CA $_{\text {board }}$ & $23.95 \mathrm{AXY}^{b}$ & $35.22 \mathrm{AY}$ & $48.86 \mathrm{CY}$ \\
R-CA $_{\text {port }}$ & $29.25 \mathrm{AY}$ & $38.08 \mathrm{BY}$ & $64.45 \mathrm{CZ}$ \\
R-CA $_{\text {residual }}$ & $29.25 \mathrm{AY}$ & $32.29 \mathrm{AY}$ & $44.65 \mathrm{BY}$ \\
R-ice & $19.76 \mathrm{AX}$ & $22.22 \mathrm{AX}$ & $19.69 \mathrm{AX}$ \\
\hline
\end{tabular}

${ }^{a} \mathrm{R}$-ice, stored in ice; $\mathrm{R}-\mathrm{CA}_{\text {board }}$, onboard CA treatment; R-CA $\mathrm{A}_{\text {port }}$, in-port CA treatment; $\mathrm{R}-\mathrm{CA}_{\text {residual }}$, stored in ice after in-port $\mathrm{CA}$ treatment for $48 \mathrm{~h}$ (residual effect).

${ }^{b}$ Different letters $(\mathrm{A}, \mathrm{B}, \mathrm{C})$ in the same row indicate significant differences $(P \leq 0.05)$ as a function of storage time; different letters $(\mathrm{X}, \mathrm{Y}, \mathrm{Z})$ in the same column indicate significant differences $(P \leq 0.05)$ as a function of treatment.

sulfited treatments, except for the treatment kept on ice from the outset, which as previously mentioned had the lowest counts. After storage for 10 days, the TVCs in all the treatments treated with 4-hexylresorcinol were slightly lower than in the treatments dusted with $4 \%$ sulfites (commercial product). After 2 days counts were slightly lower in the $\mathrm{CA}_{\text {board }}$ treatment, but this effect was not prolonged until the end of storage, when there were no differences between the different CA treatments, including the treatment testing the residual effect of the $\mathrm{CO}_{2}$ during storage. Consequently, from a microbiological standpoint, once again the washing effect of the melting ice seemed to outweigh the protective effect of the CA.

The use of a combination of CA and 4-hexylresorcinol did not afford any definite advantage in terms of the luminescent bacterial counts (Table 6), which in some cases were slightly higher than in the sulfited treatments, particularly at the end of storage.

LAB counts were low and similar in all the treatments until day 7 (Table 6). After storage for 10 days appreciably lower growth than in the sulfited treatments was observed (Table 4). It is possible that 4-hexylresorcinol could inhibit $\mathrm{LAB}$, too. As in the two cases previously discussed above, the shrimp stored on ice without CA treatment had the lowest LAB counts.

After storage for 10 days, presumptive enterobacterial counts in the CA treatments were below the limit of $10^{3}$ CFU/g (Table 6) and were lower than in the corresponding sulfited treatments. This may be due to the presumable antimicrobial effect of 4-hexylresorcinol. Moreover, storage in ice from the time of capture or after $48 \mathrm{~h}$ under CA treatment $\left(\mathrm{CA}_{\text {residual }}\right)$ proved ineffective in delaying the growth of these microorganisms.

The combination of melanosis inhibitor plus CA treatment under refrigeration without ice was more effective in preventing black spot development than conventional cold storage in which the shrimp are treated with melanosis inhibitor and covered with ice. However, early CA treatment onboard ship did not yield any apparent improvement com-

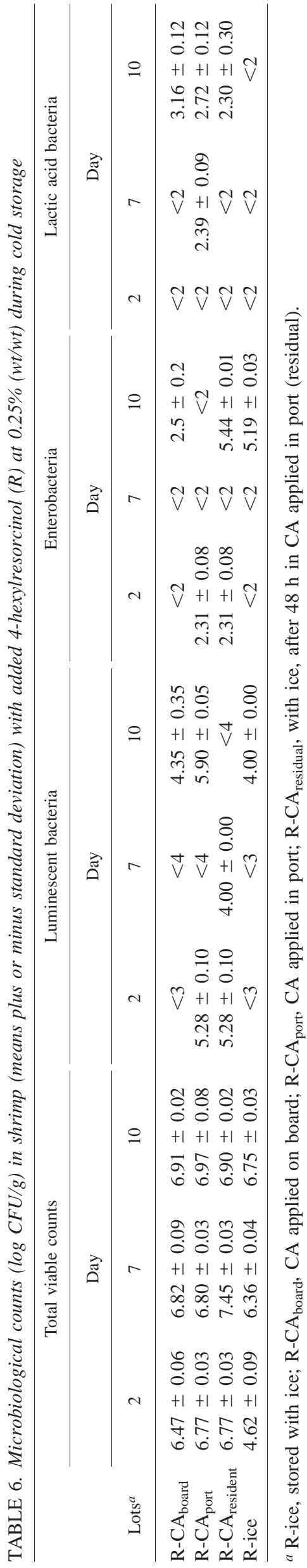


pared with treatment in port approximately $8 \mathrm{~h}$ later. Applying $0.25 \%$ 4-hexylresorcinol proved to be more efficient in inhibiting black spot formation than applying a $4 \%$ concentration of a commercial sodium metabisulfite-based product. Additionally, 4-hexylresorcinol was a more effective inhibitor of enterobacteria and lactic acid bacteria than sulfites, which, conversely, were more effective against luminescent bacteria.

Microbiological quality (TVBN content and TVC) of shrimp stored without ice under a controlled atmosphere consisting of $48 \% \mathrm{CO}_{2}$ and $7 \% \mathrm{O}_{2}$ was severely compromised as a consequence of the absence of melting ice effect. Luminescence bacteria and LAB counts were high because of the high levels of $\mathrm{CO}_{2}$, and they could be the main spoilers. The presence of a high population of $\mathrm{LAB}$, combined with the high $\mathrm{CO}_{2}$ content, might inhibit presumptive enterobacteria, as compared to conventional treatment in ice.

\section{ACKNOWLEDGMENTS}

This work was funded by the Consejería de Agricultura y Pesca de la Junta de Andalucía [Department of Agriculture and Fisheries of the Autonomous Government of Andalusia] (project CSIC-2000-664). The authors express their thanks to the Centro de Investigación de Cultivos de Especies Marinas (CICEM) [Marine Species Culture Research Center] and particularly to its director, José Naranjo, for cooperation in carrying out this study.

\section{REFERENCES}

1. Antonacopoulos, N., and W. Vyncke. 1989. Determination of volatile basic in fish. Z. Lebensm. Untersuch. Forsch. 189:309-316.

2. Bartolo, I., and E. O. Birk. 1998. Some factors affecting Norway lobster (Nephrops norvegicus) cuticle polyphenol oxidase activity and blackspot development. Int. J. Food Sci. Technol. 33:329-336.

3. Chen, H. M., S. P. Meyers, R. W. Hardy, and S. L. Biede. 1984 Color stability of astaxanthin pigmented rainbow trout under various packaging conditions. J. Food Sci. 49:1337-1340.

4. Chinivasagam, H. N., H. A. Bremner, and R. Reeves. 1998. Can spoilage bacteria cause blackspot (melanosis) in stored prawns? Lett. Appl. Microbiol. 27(1):5-8

5. Chinivasagam, H. N., H. A. Bremner, S. J. Thrower, and S. M. Nottingham. 1996. Spoilage pattern of five species of Australian prawns: deterioration is influenced by mode of storage. J. Aquatic Food Prod. Technol. 5:25-50.

6. Dalgaard, P. 1995. Modelling of microbial activity and prediction of shelf life for packed fresh fish. Int. J. Food Microbiol. 26:305-317.

7. Dalgaard, P., O. Mejholm, T. J. Christiansen, and H. H. Huss. 1997. Importance of Photobacterium phosphoreum in relation to spoilage of modified atmosphere-packed fish products. Lett. Appl. Microbiol. 24(5):373-378

8. Davis, H. K. 1998. Fish and shellfish, p. 194-239. In B. A. Blakistone (ed.), Principles and applications of modified atmosphere packaging of foods, 2nd ed. Blackie Academic Press and Professional, Glasgow, Scotland.

9. deMan, J. D., M. Rogosa, and M. E. Sharpe. 1960. A medium for the cultivation of Lactobacilli. J. Appl. Bact. 23:130-135.

10. Ferrer, O. J., J. A. Koburger, B. K. Simpson, R. A. Gleeson, and M. R. Marshall. 1989. Phenoloxidase levels in Fla. spiny lobster (Panulirus argus): relationship to season and molting stage. Comp. Biochem. Physiol. 93B:595-599.

11. Ferrer, O. J., W. S. Otwell, and M. R. Marshall. 1989. Effect of bisulfite on lobster shell phenol oxidase. J. Food Sci. 54(1):63-67, 176.

12. Guandalini, E., A. Ioppolo, A. Mantovani, P. Stacchini, and C. Giovannini. 1998. 4-Hexylresorcinol as inhibitor of shrimp melanosis: efficacy and residues studies: evaluation of possible toxic effect in a human intestinal in vitro model (Caco-2): preliminary safety assessment. Food Additives Contam. 15(2):171-180.

13. Haard, N. F. 1992. Technological aspects of extending prime quality of seafood: a review. J. Aquatic Food Prod. Technol. 1:9-27.

14. Huss, H. H. 1988. Fresh fish. Quality and quality changes. FAO Fisheries Series No. 29.

15. Lannelongue, M., G. Finne, M. O. Hanna, R. Nickelsen, and C. Vanderzant. 1982. Storage characteristics of brown shrimp (Penaeus aztecus) stored in retail packages containing $\mathrm{CO}_{2}$-enriched atmospheres. J. Food Sci. 47:911-913, 923.

16. Lannelongue, M., G. Finne, and R. Nickelson. 1981. Brown shrimp (Penaeus aztecus) packed in modified atmospheres containing carbon dioxide, p. 206-214. In Proceedings of the 6th Annual Tropical and Subtropical Fisheries Technological Conference of the Americas. San Antonio, Tx.

17. Layrisse, M. E., and J. R. Matches. 1984. Microbiological and chemical changes of spotted shrimp (Pandalus platyceros) stored under modified atmospheres. J. Food Prot. 47(6):453-457.

18. López-Caballero, M. E. 1998. Flora alterante de merluza (Merluccius merluccius $L$ ) refrigerada sometida a concentraciones variables de $\mathrm{CO}_{2} \mathrm{y} \mathrm{O}_{2}$. Identificación y actividad bioquímica de bacterias implicadas en el deterioro. [Spoilage microorganisms of chilled hake (Merluccius merluccius $L$ ) stored under variable concentrations of $\mathrm{CO}_{2}$ and $\mathrm{O}_{2}$. Identification and biochemical activity of spoilage bacteria]. Ph.D. thesis. Faculty of Veterinary, Complutense University, Madrid, Spain.

19. López-Caballero, M. E., A. Gonçalves, and M. L. Nunes. 2002. Effect of $\mathrm{CO}_{2} / \mathrm{O}_{2}$ containing modified atmospheres on packed deepwater pink shrimp (Parapenaeus longirostris). Eur. Food Res. Technol. 214:192-197.

20. Maldhavi, D. L., S. S. Desphande, and D. K. Salunkhe. 1995. Food antioxidants. Marcel Dekker, New York.

21. McEvily, A. J., R. Iyengar, and S. Otwell. 1991. Sulfite alternative prevents shrimp melanosis. Food Technol. 45(9):80-86.

22. Mendes, R., A. Huidobro, and E. López-Caballero. 2002. Indole levels in deepwater pink shrimp (Parapenaeus longirostris) from the Portuguese coast. Effects of temperature abuse. Eur. Food Res. Technol. 214(2):125-130.

23. Montero, P., M. C. Gómez-Guillén, P. Zamorano, and O. MartínezÁlvarez. 2003. Estudios de los agentes conservantes e inhibidores de la melanosis en crustáceos. Junta de Andalucía. Consejería de Agricultura y Pesca. [A study on preservative and inhibitory agents in crustacean melanosis. Government of Andalusia. Agriculture and Fisheries Department]. Spain.

24. Ogawa, M., N. B. Perdigão, M. E. Santiago, and T. T. Kozima. 1984 On physiological aspects of blackspot appearance in shrimp. Nippon Suisan Gakkaishi 50:1763-1769.

25. Otwell, W. S., R. Iyengar, and A. J. McEvily. 1992. Inhibition of shrimp melanosis by 4-hexylresorcinol. J. Aquat. Food Prod. Technol. 1(1):53-65.

26. Rosen, A., and R. E. Levin, 1970. Detection and incidence of Escherichia coli on storage pen surfaces of fishing trawlers. Appl. Microbiol. 20(1):103-106.

27. Sivertsvik, M., W. K. Jeksrud, and J. T. Rosnes. 2002. A review of modified atmosphere packaging of fish and fishery products-significance of microbial growth, activities and safety. Int. J. Food Sci. Technol. 37:107-127.

28. Spreekens, 1974. The suitability of a modification of Long and Hammer's medium for the enumeration of more fastidious bacteria from fresh fishery products. Arch. Lebensm.hyg., 25(10):213-219.

29. Stammen, K., D. Gerdes, and F. Caporaso. 1990. Modified atmosphere packaging of seafood. Crit. Rev. Food Sci. Technol. 29:301331.

30. Stenström, I. M., 1985. Microbial flora of cod fillets (Gadus morhua) stored at $2^{\circ} \mathrm{C}$ in different mixtures of carbon dioxide and nitrogen/ oxygen. J. Food Prot. 48:585-589.

31. Taylor, S. L., and R. K. Bush. 1986. Sulphite as food ingredients. Food Technol. 40:47-52.

32. Warner, C. R., G. W. Diachenko, C. J. Bailey. 2000. Sulfites: an important food safety issue. Food Test. Anal. August/September:1-4. 